\title{
Practices of the Great Green Wall Project in the Ferlo (Senegal): Effects on Pastoral Resilience and Development
}

\author{
Amadou Ndiaye $e^{1, *}$ \\ ${ }^{1}$ Faculty of $S 2 A T A$, Gaston Berger University of Saint-Louis, Senegal \\ *Correspondence: Faculty of S2ATA, Gaston Berger University of Saint-Louis, Senegal. E-mail: \\ amadou.ndiaye@ugb.edu.sn
}

Received: February 4, 2016 Accepted: February 24, 2016 Online Published: March 11, 2016

doi:10.5430/wjss.v3n2p1 URL: http://dx.doi.org/10.5430/wjss.v3n2p1

\begin{abstract}
To support the ecosystem resilience in the sylvo-pastoral area, Senegal did pioneering work by initiating, since 2008, field activities in the framework of the pan-African project of the Great Green Wall (GGW). How have the Senegalese practices contributed to the pastoral resilience and development? What are the lessons that the Pan African Agency and the Sahelian countries involved can draw from the Senegalese experience? To answer these questions, this study proposes to identify the major characteristics of the GGW practices as well as the effects on pastoralism in a comprehensive and strategic perspective, following an inductive approach.

The Great Green Wall looks like a sectorial project (forest) with diversification activities (horticulture). The way field workers perceive it is not homogeneous. Reforestation plots have impacts on the resilience of the courses and the populations. They modify the grazing plans and encourage private fodder banks to the detriment of traditional pasture reserves. Several actions (distribution of food, medical consultations, employment) of the Great Green Wall contribute to the resilience of the pastoral populations (health, food security and income). The Great Green Wall also has effects on social transformation and pastoral development. There is a noticeable change of mindset, a development of civic awareness, as well as a breakdown of their social isolation.

To become a systemic project development, the GGW could integrate production sectors such as hydraulics and education. To accomplish this, the agency must hire a multidisciplinary staff with a corporate culture to break away with participative behaviors.
\end{abstract}

Keywords: Great Green Wall, resilience, pastoralism, sectorial, approach, systemic approach

\section{Introduction and Problem}

The sylvo-pastoral area (SPA) in Senegal forms part of the Sahel. The annual rainfalls range from 150 to $600 \mathrm{~mm}$ (Hiernaux et al, 2006). It is an arid region where years of good and poor rainfall alternate on an irregular basis. The years going from 1951 to 1969 were rainy; whereas the period going from 1970 to 1993 was marked by a succession of dry years. The period 1994-2011 is characterized by a rainy year followed by 3 or 4 dry years (FAO et CIRAD, 2012). The irregularity results in shocks that lead to a vulnerability and resilience of the Sahelian ecosystem. Each year of good rainfall, the vegetation grows again while it undergoes adverse shocks in 2-4 months in case of drought. The rain also enables the filling of temporary pools and valleys (rivers) that are more or less sandy as well as groundwater table. Thus, in the SPA, plant formations are largely dominated by shrub-steppe even if one can find wooded steppes and in some spots some gallery formations in the South. To face these shocks, the shrub flora developed thorns to better fight against evapotranspiration while the herbaceous flora "chooses" to complete its growth cycle. The seeds produced are weather-resistant over several years (wind, brightness and drought, heat). This flora resilience capacity enables to better fight against Sahelian vulnerability.

To cope with these changing rainfall conditions and ecosystem vulnerability, people have adopted pastoralism as a system of livestock production and a populations' way of life that is practiced in the arid and semi-arid areas of the world. Thus, pastoralism is a form of exploitation of domestic ruminants through irregular intervals shocks: context of rainfall and meteorological sway, scarcity of natural plant and hydric resources, natural (drought, epidemic) and 
anthropogenic risks (conflicts, competition for access the resources, brush fire, etc.). Recent estimates indicate that 50 millions of the pastoralists and agro-pastoralists are located in sub-Saharan Africa (Toure and All, 2012). In West Africa, pastoral systems provide over $80 \%$ of the rural people's income, and they represent an important source of milk and meat for the urban people (Toure and All, 2012).

Pastoral practices are primarily based on the choice of the animals' races, knowledge of the flora (partiality, toxicity, drug virtue, rarity / abundance), the characterization of surface water and groundwater points, habitat and camps' development, the zoning of pastures (close, medium, remote and reserve), traditional veterinary sciences, the composition of herds, the selection of the genetic potential of livestock breeds, production, the production and preservation of milk, the exploitation of other forest resources (picking), social relations, exchange (barter), etc. These resilient traditional practices also take into account other anthropogenic risks (conflicts, tribal lineage, competition, complementarities). They are designed based on a mobility strategy that enables to respectively face the cyclical resource scarcity as well as natural disasters (drought, flood, epidemic) and anthropogenic (conflicts, bush fire, etc.) risks.

The drought of 1970 has resulted in the worsening of shocks and the vulnerability of ecosystems. The government responded by setting up development projects. In the SPA, these projects have been implemented on a sectorial approach:

- Animal health and breeding: the fight against epizootic diseases, livestock backup, and vaccination park.

- Hydraulics: Boreholes and pastoral wells, ponds' development

- Forestry: reforestation and development of areas, recovery / restoration of soils.

This sector-based approach (livestock, hydraulics, water and forests) puts the focus on supporting ecosystem and animal resilience. It does not take into account the pastoral practices and thus optimally ignored the vulnerability and resilience of populations. These projects were first implemented in an authoritarian way before using a participatory approach. However, the analysis of the interaction system of the development projects reveals that the "participatory model" results in a development of participative behavior among stakeholders and a participationist one among beneficiaries (Ndiaye, 2013).

Despite the efforts made, climate change is likely to exacerbate and intensify the frequency and magnitude of droughts and desertification, and the scarcity of water sources and plant resources. They increase the vulnerability of ecosystems and populations in times of conflict, insecurity and political instability in the Sahel with adverse effects on the socio-economic field (low income, malnutrition, poor access to health care) and the socio-political one (generation gap, robbery of cattle, idleness, religious indoctrination, etc.).

It is in this context of global change that the African Union has decided to set up the Great Green Wall (GGW) in 2007. The GGW, with its paradigmatic and fussy context, was supported by the strong and affirmed political will of some leaders, including the then-President of Senegal. This political led to a quick establishment of an agency and field activities in the winter of 2008. Today, a Pan-African Agency of the Green Belt is operational and some Sahelian countries (Chad, Burkina Faso) have begun carryout out field actions.

Which lessons can APGMV (Pan-African Agency for the Great Green Wall) and the involved Sahelian countries learn from the Senegalese experience? To what extent have the GGW practices in Senegal contributed to the resilience and the pastoral development?

Today, the International Community agrees on the need to develop strategies for socio-political stability and the strengthening of pastoral resilience in the Sahel region to deal with the vulnerability of breeders, livestock and routes (water, pasture, and corridors). Pastoralism has been retained as a strategy for resilience, development and socio-political stability. Beyond the projects of the ECOWAS (Economic community of West African states), the WAEMU (West African Economic Monetary Union), and the Permanent Interstate Committee for Drought Control in the Sahel (CILSS), the project CILSS / SIPSA (Information System on Pastoralism in the Sahel) and the international certificate of transhumance, the African Union has adopted a strategic framework for pastoralism in Africa in October 2010. In addition, the frameworks of actions have been shared at the regional Ministerial Symposium on pastoral breeding in Chad (in May 2013) and at the high-level Forum on pastoralism in Mauritania (October 2013). The Declaration of Ndjamena and the Declaration of Nouakchott express the consensus of the major international actors and donors (World Bank, African Development Bank, European Union) and reiterate their commitment to pastoralism. Thus, the international community agrees that pastoralism is a strategy of development and socio-political stability as well as a means to build resilience. 
How do ecosystem restoration actions contribute to the resilience of Sahelian rangelands and populations? To address this question, the study has been conducted on the basis of field works of the Green Belt in the sylvo-pastoral area in Senegal?

The general objective of this study is to determine the effects of the practices of the Great Green Wall in Senegal on resilience and pastoral development. The following specific objectives have been set:

- describe the organization and the implementation of the actions of the GGW

- determine how the field staff and the populations respectively perceive the project and the actions of the GGW

- identify the effects of actions on pastoralism

- analyze practices in the field and the effects from a resilience and pastoral development perspective.

\section{Methodology}

An inductive methodology, essentially based on the collection and analysis of qualitative data, was set up.

To collect the data, several site visits were done. These visits helped make observations and group or non-formal and informal individual or group interviews in the Great Green Wall's reserve. Interviews were held with people acting for the development of the area and the residents.

A total of 15 stakeholders were interviewed. They include seven agents of the GGW, the head of the departmental Service of water affairs and forests, two agents of the veterinary service, the Prefect and two former agents of the German forestry project. Moreover, a focus group was created with the team of PASA LOUMAKAF (Assistance Project Program for Food Security).

As far as the local populations are concerned, interviews were conducted with the direct and indirect beneficiaries. The first group includes the members of the Female Empowerment Group (FEG), the rangers of the reforestation plots and young workers in plant nurseries.

"Indirect beneficiaries" comprise 45 local cattle breeders, 9 transhumant families in their camps and stakeholders of the area's weekly markets ( 3 mobile phone chargers, 6 shoemakers and shoeshine boys and 10 traders) and sheet metal workers (Widou and Labgar) working at the boreholes.

The two themes addressed during these interviews are the practices of the Great Green Wall on the one hand and secondary effects on the other. Concerning the practices, the questions asked include the missions and strategies of the Green Belt, its organization and field operations, and its activities and prospects. The theme of secondary effects focused on the everyday life and local dynamics (food, social relationship, income), pastoral land development, pastoral practices (water, grazing, movement, harvest of fruit, predator), the cattle (production and productivity, animal health, income), ecosystems and the environment (climate change, evaluation of the carbon footprint).

For a better understanding of these data, a content analysis (categories of actions and effects) was performed. It enabled to identifying the identification of strategies (liability, organization, approaches, etc.), characterizing the intervention (perception of the stakeholders, communication, relationship and conflict management) and identifying the relationship between the actions of the GGW and pastoralism. For this purpose, EXCEL tables were developed. One category was entered in each column. Then sorting outs, checks and arbitrations were carried out to better identify sectors and their eventual impacts on pastoralism.

\section{Results}

This section first presents the basic organization and the perception of stakeholders on the GGW and then the sector-based actions (respectively forestry, horticulture and others) and their effects.

\section{a. Field organization and perceptions}

The Agency of the Great Green Wall in Senegal works at the basis with a shared staff and its own personnel. The National Agency of the Great Green Wall (NAGGW) has signed an agreement with the Directorate of Water, Forest, Hunting and Soil Conservation (DWFHS) to use its agents in forest stations crossed by the Green Wall. Thus, the NAGGW shares 5 agents with the service of water affairs and forests. These agents continue to have a dual mission of actions' management of the NAGGW and forest police.

The GGW Agency's own staff consists of a forest technician posted to Mbar Toubab (under the supervision of the 
SYER Post's Chief) and horticultural technicians in the four rural communities (Mbar Touba, Widou Thiengolly, Téssekré, Labgar, louguéré Thiolly).

In the field of the Senegalese SPA, forest officers have the same paradigmatic perception of the GGW's project. All the GGW's officers encountered continue to believe that the GGW is a "project to stop the desert's advance in the North." For them, it is necessary to build a "Tree wall that would bring back the rain." Some consider themselves as "mere executives of the orders of their higher hierarchy" of the Agency of the Green Wall. They notice that there is no coordination meeting between agents of the Green Wall, except when the plant nurseries period gets closer. They even wonder whether their quarterly reports "are exploited" by the authorities. They denounced "the lack of information and the physical absence of the authorities."

In the pastoral perspective of this study, perceptions of other actors have been identified. The authorities of the territorial administration are convinced that the Green Wall has economic development ("production of milk, meat, leather and even vegetable products" and infrastructure development ("rural roads to open up, 32 boreholes and other infrastructures ") dimensions. For them, the GGW will bring peace in the area. "Over 3 years, I have witnessed only one crisis meeting concerning the Great Green Wall's Agency, "said the Prefect.

The veterinary service agents are convinced that there is no link between the GGW and cattle breeding Department Service. For them, the GGW does not take into account the water shortage issue that is fundamental in the area. Some veterinary service agents (IDSV- Linguere) would like the agency of the Green Wall to involve them in their activities. The agents of some of the pastoral breeding development projects (PASA Loumakaf) believe that the Green Wall project is incompatible with their projects. Many agents believe that "there is a lack of coordination between projects in the area."

Beyond the perception, the field agents have been implementing actions in several sectors.

\section{b. Forestry Sector and pastoralism}

The forest sector is the main sector of intervention of the GGW. The objective is to set up reforestation plots the areas of which have varied over time. A plot covers has a minimum 200 hectares surface. All the rural communities (Mbar Toubab, Téssékré, Labgar and Louguéré Thiolly) have their own reforestation plots. Reforestation activities began in 2008 in the rural community of Téssekré (Widou Thiengoly) with 4 plots of 500 hectares including one with no fence. As of 2009, the number of plots has been increasing in the other rural communities without being provided with fences. For example, none of the four reforested plots with a surface of 500 hectares, 650 hectares and 750 hectares had a fence. In the rural area of Labgar, only of the 04 reforested plots identified had a fence. This fenced plot was reforested in September 2009 in collaboration with the French and Senegalese armies, EIFFAGE and TOTAL. Yet, in the community of Mbar Toubab where reforestation activities only began in 2010, there are 07 plots 06 of which have fences. In this area, activities are carried out through a partnership with SOUKEYA, a Japanese organization. Over all, half of the plots (10 out of 20) have fences: Widou Thiengoly (4 out of 5), Mbar Toubab (6out of 7) Labgar (1 out of 4), Louguéré Thiolly (0 out of 5).

The setting up of these plots is normally subject to a process. The sites to be reforested are proposed by the village Chiefs after the approval of the villagers. The geographical coordinates (identified by GPS) of the proposed plots are then submitted for evaluation/ appreciation to the National Directorate of the Agency of the Great Green Wall for validation or invalidation in case their dimensions extend beyond the designated area. If the site laid out is validated, the Rural Council is associated in the approval process. It should make sure local people are not displaced to set up plots. Theoretically, each plot should be surrounded by firewalls, be it fenced or not.

Beyond their adaptation to the Sahelian climate, the choice of species to reforest rests depends on two factors: they should not be comestible for animals and they should have a forestry importance (production of gum arabic and fruit production). Thus, five species have been retained: Acacia radiana, Acacia senegal, Acacia seyal, Balanites aegyptiacaand Zyziphus mauritiana

For the management of activities, a yearly coordinating meeting is summoned (the "only" one according to the agents' report) during the month of May. After that meeting, plant nurseries are set up to allow the plants to grow and be ready for reforestation by the month of August. The weeding and the opening of firewalls are done in October.

The planting in lines has been retained as a type of sowing because it enables "an increase of the density." At the beginning, the distance between plants was $5 \times 5$. Today it is reduced to $5 \mathrm{X} 10$. However, we notice that the less than two years old plots are always replenished, especially "those planted by students who lack experience (agents report) (Mbar Toubab). Elsewhere (Louguéré Thiolly), it is noticeable that the distances are not respected. "The 
spacing between plants is not respected because of the natural regeneration", some field workers answered.

The technical difficulties are related to the quantification of the plants, the destination of the seeds in plastic sheets and the expertise of the summer volunteers. Everywhere, it was observed that a significant amount of nursery plants withered then died in their plastic sheaths during the month of April. These were nursery plants of the previous year. An agent helped us better understand the impact of this phenomenon: "Every year, about 30,000 plastic sheaths containing the plants are buried or burned," even if "all the plots reforested by students are replenished later on."

The implementation of reforestation plots has effects on pastoralism. On the field, there are some effects on the pastoral rangeland and the transhumance circuits. There is first a change of the plan of grazing. Indeed, some cattle farmers find that plots are too close to their hamlets. Thus, in the long run, they will impede the traffic of at least one component of the livestock. Indeed, calves and cows graze in opposite directions in order to enable the owners (families) to take the milk before the calves feed themselves. Thus, the plots of the GGW have an indirect effect on food and family income sources.

Besides, it is necessary to note again a slight effect in the availability of fodder. The plots also produce straw and pod that people should be able to exploit. In the area of Mbar Toubab, from June and "for 45 days, every week, a maximum of 100 permits are issued freely for the exploitation of the plots." Thus, "the local people can have a five-day permit every week contrary to outsiders (usually transhumants) who have two days renewable ". So, to have access to the fodder, farmers have to go through the service of water affairs and forests. This situation is variously appreciated. According to the same agents, "The organization operates in such a way that the inhabitants consider themselves entirely as the owners of the plots to the point of acting as policemen and these results in fewer offenses." However, they are quick to add "those who commit offenses are taken in custody for 48 hours. Beyond that period, they are sent to jail if they do not pay the bail. Some farmers however note that that "there is a total confusion concerning the access permits to the plots because they choose collaborators among us."

Beyond these confusions, farmers particularly denounce the difficulties of providing animals with water to drink when tree nurseries are being set up (May-July). During this dry and hot period, the bovine cattle drink only one day over two. Breeders believe that "since the creation of tree nurseries, creatures without soul (plants) are privileged to the detriment of creatures with souls (cattle)."

Beyond the rangelands, the reforestation plots also enable the populations to diversify their sources of income through the establishment of tree nurseries (May to August) and the reforestation (August and September) and the surveillance of plots (October June). Theoretically, this activity constitutes an important source of income (35,000 CFA francs a month for the guarding) but on the field, some say that the workers do not respect the duration and the officially fixed amounts because the contracts are unwritten and informal. In some areas (Tessékré-Widou and Labgar), we have not met any guard while elsewhere (in Mbar Toubab and Lougueré) the guards only show up if they are informed, in advance of our arrival. Confidentially, some guards explain that they are only paid 5 out of the 9 planned months.

The plastic sheaths for seed nurseries are either burned or buried. Although it appears difficult to measure their impacts within this study, it is certain that these plastic bags have short or long-terms environmental effects considering their quantity.

\section{c. Horticultural sectors and pastoralism}

In all the rural communities, the Great Green Wall works with a Female Empowerment Group (FEG) that sets up multi-purpose gardens. To this end, four horticultural agents have been recruited by the FEG to accompany horticultural productions. The areas of the multi-purpose gardens vary from 5 ha (Téssekré and Mbar Toubab) to 7.5 ha (Widou Thiengolly). In general, one part (one third or one half) is devoted to gardening and the rest to the cultivation of fruit trees.

To manage these gardens, women are organized in Economic Interest Group (EIG) comprising 145 members (Mbar Toubab). They are divided into groups of 20 to 50 people who relay each other. In some areas, there are 6 or 7 groups (Widou, Labgar) and each group only comes one day a week. In other areas, there are 3 groups and each group comes twice a week, except on the day of the weekly market.

The technical training has been provided by the Agency of the Great Green Wall; however, they claim they have not yet have received any retraining (Labgar), even if the daily monitoring is performed by horticultural agents of the GGW. Technically, the gardens are equipped with an operational drip irrigation system although women use watering cans of 20 liters, especially in Labgar. 
Women run the garden with full sovereignty; they decide which expenditure has priority. In general, inputs (seeds, fertilizers), the small equipment as well as the water are provided by the Agency of the Great Green Wall, but women may buy additional seeds. This was the case in Mbar Toubab. The women of this locality decided to fire the security guard because they could not afford it. They involve local mutual and credit banks in their loan process (Mbar Toubab). Everywhere, the harvested crops (fruits and vegetables) are sold cash or credit to group members in the garden. The money from the harvest is then loaned to women who pay back within a maximum period of 5 months with a $10 \%$ interest rate.

However, women face several difficulties. In general, they complain about the lack of water and the delay in the availability of the inputs that are in addition deemed insufficient. In Widou, they denounce the theft of scrap metal and the vulnerability of the fence that is not high and strong enough to resist against small ruminants and thieves.

The actions in the horticultural sector have effects on pastoralism. In general, the activities of the multi-purpose garden put additional pressure on the availability of water. For farmers, "the multi-purpose gardens are not compatible with pastoralism," the farmers say even if they acknowledge that they "gardens improve the quality of meals". Beyond that, these gardens also have economic effects on the members of the FEG. Indeed, the money gained from the sale of crops is then lent to women who pay back within a period of 5 months with an interest rate of $10 \%$. They set up as a kind of "tontine", which enables those who want to fund other activities to do so. For example, some women buy bags of millet that they loan each other other for 2 to 5 months.

Yet, most women seem to appreciate more the social dimension of the multi-purpose gardens rather than its economic aspect. The gardens allow women to "escape" the routine daily housework and especially to break the social isolation imposed by the scattered habitat. Gardening activities reinforce the solidarity between women. In addition, the proximity of the garden enables them to get commodities nearby and not to go to Ndioum or Linguere.

\section{d. The other sectors and pastoralism}

Next to these two key sectors, field actions also concern the water sector, the social sector and the sector of tourism whereas poultry farming and fish farming would be longer-term targets.

In the water sector, the intervention of the GGW is not systematic. Nevertheless, two major actions were carried out, especially in Labgar. These include the establishment of a retention basin even though people say that the investment did not, in any circumstance, change the functionality of the former temporary pond. For them, "the basin retains water only for a very short time." However, they highly appreciate the GGW's 30, 000 francs CFA investment to change the drilling machine. People consider that it is "the best operation carried out" by the agency in the area.

In the social sector, the agency of the Great Green Wall is involved in food and nutrition security by distributing food to the populations. The latter regret the fact that these actions are no longer performed. Moreover, people benefit from free medical consultation days with 'the Red Cross and the Ministry of Youth during periods of reforestation".

The Great Green Wall had initiated a touristic project through the establishment of an animal reserve for the community in the reserve pastures between Widou and Tessékré. The populations who made it fail despite the intervention of the Prefect strictly rejected this project. The President of the Rural Council and the majority of people were strongly opposed to the creation of an animal reserve despite the exchange visit organized by the GGW at Bandia animal reserve and the National Sanctuary of Birds at Djoudji (PNOD). The minority that supported this project lives in the western area of the boreholes of Widou towards Mbar Toubab, an area that was not contiguous to the reserve pasture. Beyond the immediate interest of conserving a grazing reserve area, this project stirred latent social conflicts between the communities that live in the Western and Eastern areas of the boreholes of Widou that date back from the establishment of the plots of the German Project in the area. The conflict finally affected the whole forestry-pastoral area as a result of the game of alliances. The population in the area of Labgar radically stood up against the project while that of remote Thiargny (the place of origin of the implementing Minister) attempted to support the project.

The opposing populations diplomatically retort that "the reserve would not be profitable to them due to the fact they do not have the capacities to build and maintain it." Those who are for the project argue that nobody has the right to oppose the power of the State. Administratively speaking, the project did not meet the standards of the forest areas' classification in Senegal. Indeed, the sylvo-pastoral area of Senegal is divided into four main protected/classified areas. In the West, there is the sylvopastoral Reserve of the North (the area of the conflict) and the sylvopastoral reserve of the South. In the East, we have the Fauna Reserve of the Northern Ferlo (RFFN) and the Fauna Reserve of the Southern Ferlo (RFFS). The GGW should extend through the territories of the Fauna Reserve of the Northern Ferlo (RFFN). It is likely to succeed and make investments on the wildlife fauna. 
It is remarkable that in the pastoral areas the GGW has no actions that directly concern the production sector and animal health.

\section{Discussion / Conclusion}

The technicians of the water affairs and forestry service, those of the breeding service and projects still have a sector-based perception (forestry) of the Great Green Wall Project while the administrative authorities believe that it is a holistic one. This analysis goes beyond the field actions. From field actions, the GGW constitutes effectively a forestry project with diversified actions including horticulture.

Despite the proliferation of reforestation plots, it is not easy to draw the conclusion that steppes are resilient in terms of ecosystem. There has been, of course, the introduction of plant formation but their lines distances do not necessarily correspond to those generally defined for a steppe. However, in the long run, once the fences are removed and interactions with the physical and social environment regularly happen, ecosystem resilience will be more perceptible. Currently, there is a change of pastoral rangelands plans for those who are close to the reforestation plans. Moreover, the difficulty to have access to water caused by horticultural gardens and plant nurseries has an effect on the time and the organization of the pasture. Furthermore, reforestation sites are "fodder banks" while the local pastoralism works more with grazing reserves areas.

The resilience of the pastoral people in what could be called goodwill of the GGW. It concerns health and food security and societal transformation. It consists first in distributing food (food security), organizing medical consultations and buying pumps for the drilling. The recruitment of young people as temporary employees (in nurseries, reforestation and guarding) also contributes to the pastoral resilience of families because it enables to increase and diversify incomes in pastoral farms. However, these actions can also be considered as social transformation and pastoral development ones.

Indeed, the provision of paid jobs to young people in full sylvo-pastoral areas represents an important development element which starts influencing people's mind. It not only enables to have income but, above all, it contributes to peace and security in the area. A lady clearly reinforces our view when she states: "You must find jobs for our children, otherwise they will become cattle thieves, drug addicts and alcoholics."

Moreover, beyond the contribution to the quality of food and income from tontines, the multi-purpose gardens help break the isolation of rural women in their camps and their hard labor of fetching water from the boreholes. The women's multi-purpose garden creates new bonds and strengthens the solidarity between them. The loans made via tontines encourage women to work harder to preserve their Fulani moral integrity. Thus, in the sovereign management of the multi-purpose garden, they make decisions and arbitrate between expenditures (purchase of inputs, removal of guards). In reality, activities and relationships in the gardens create a socialization that allows them to acquire new skills and strengthen their capacities.

Basically, the actions of the GGW in the SPA of Senegal has an important dimension on gender issue enabling women to strengthen their capacities and young people to have access to employment. These two types of actors hope for an economic development going beyond the gardens. In fact, women want to better learn how to process and preserve the milk but also to sew or to grind cereals with machines...Above all, they want their children to attend schools. Consequently, a small reorientation towards the water sector is expected to free women and children from water duty, especially during school time unless an adaptation of the school calendar is negotiated in this area.

In any case, the project GGW obviously endeavors to go beyond ecosystem resilience to become a development project. Nevertheless, it is still dominated by a sectorial approach which does not facilitate the integration of actions. This approach favors mostly participative behaviors o the part of agents and participating ones on the part of some breeders. The agents' behavior is all the more visible because they are primarily agents of the water affairs and forest water service responsible for, above all, authoritarian implementation of forestry police. Moreover, even some horticultural agents of the GGW often bear the cost of the interventionism of some forest officers, which indicates the Great Green Wall's staff lack experience and practice. This absence is responsible for the paradigm of "desert advance or tree wall "in the minds of all the field agents interviewed. The proliferation of coordination meetings, as well as the recruitment and the training of its own agents, could allow to turn the GGW into sustainable project managed by an independent agency.

This better evolution will be optimized through the creation of multidisciplinary teams but also the performance of Environmental Impact Studies to better define the orientation of the actions. These studies will help better define and consider the peace and security of the area, the income-generating sectors, the intervention approaches and the 
orientation of actions to build the capacities of the actors and their targets

\section{References}

Adriansen HK. (2008). Understanding pastoral mobility: the case of Senegalese Fulani. The Geographical Journal, 174(3), 207-222.

Ancey V., Ickowicz A., Touré I., Wane A., \& Diop A.T. (2009). La vulnérabilité pastorale au Sahel : portée et limite des systèmes d'alerte basés sur des indicateurs. In Duteurtre G., Faye B. (eds.), L'élevage, richesse des pauvres: stratégies d'éleveurs et organisations sociales face aux risques dans les pays du Sud. Versailles: Quae, 117-132.

BA C. (1986). Les peuls du Sénégal: études géographiques. Edition Nouvelle Edition Africaine: Dakar. p541.

BARRAL H. (1982). Le Ferlo des forages: gestion ancienne et actuelles de l'espace pastoral. Etude de géographie humaine. Dakar, Sénégal; ORSTOM; p85.

DIOP A.T. (1989). L'aménagement et la gestion des ressources sylvopastorales au nord du Sénégal: le cas de l'aire d'influence du forage de Tatki- Thèse de Doctorat- UCAD- Faculté des Sciences- ISE-Dakar: Sénégal; p138.

FAO et CIRAD. (2012). Système d'information sur le Pastoralisme au Sahel: atlas des évolutions des systèmes pastoraux au Sahel 1970-2012.

KANE A.S. (1978). Daa'de kooyanaa 'be - Voix des gens du Kooya. Dakar Sénégal: ENDA, Etude et Recherches n 78 - 41 décembre 1978. 65p

Ndiaye Amadou. (1996). pharmacie vétérinaires villageoises et auxiliaires d'élevage au Sénégal: cas de zone sylvo pastorale, thése N* 4 1996, EISMV-Université Cheikh Anta DIOP Dakar.

Ndiaye Amadou. (2013). Intervention pour le développement rural; conceptualisation à partir des pratiques de la vallée. thèse de socio -économie rurale, Université Gaston Berger de Saint-Louis.

Sénégal (République du), (Juillet 2013). Etude pour la création de réserves naturelles communautaires (RNC) dans l'espace du programme de la grande muraille verte - Sénégal: développement de l'écotourisme comme activité génératrice de revenus.

Touré Oussouby. (1987). Une société pastorale en mutation sous l'effet des politiques de développement : les Peul du Ferlo du début du siècle à nos jours. Unité socio-économique et de démographie, Institut du Sahel, 1987.

Touré Oussouby. (2014). Etats des lieux de la problématique du foncier pastorale au Sénégal. IPAR, Dakar.

Touré, I., Ickowicz A., Wane A., Garba, I., \& Gerber P. (eds.) (2012). Atlas des évolutions des systèmes pastoraux au Sahel 1970-2012. FAO: Rome.

Wane A., Ancey V., \& Touré I. (2010). Pastoralisme et recours aux marchés: Cas du Sahel sénégalais (Ferlo). Cahiers agricultures, 19(1), 14-20. http://dx.doi.org/10.1684/agr.2009.0329

Wane A., Diao Camara A., Ancey V., Joly N., \& Ndiobène Kâ S. (2009). Choix individuel et sécurisation collective: formes de salariat dans les exploitations pastorales du Sahel sénégalais (Ferlo). Economies et sociétés, 31(9), 1443-1468.

http://www.terraeco.net/La-Grande-Muraille-Verte-du-Sahara,11081.html

http://developpementdurable.revues.org/index3292.html 